\title{
The Curing Method Influence on Mechanical Behavior of Reactive Powder Concrete
}

\author{
Ika Bali", Wilson Kurnia* \\ ${ }^{\#}$ Research Institute, Matana University, ARA Center, Jl. CBD Barat Kav.1, Tangerang 15810, Indonesia \\ E-mail:ikabali@yahoo.com
}

*Department of Civil Engineering, University of Tarumanagara, Jl. Let. Jend. S. Parman No.1, Jakarta 11440, Indonesia

E-mail:wilsonkurnia@gmail.com

\begin{abstract}
The curing method becomes important to be considered in applying the Reactive Powder Concrete (RPC) in the field. Currently, the application of RPC in the field can be simulated with the method of steam curing at $90^{\circ} \mathrm{C}$ that resulted in compressive strength of $102 \mathrm{MPa}$. This study used some methods of curing included the method of steam curing at $90^{\circ} \mathrm{C}$ to investigate mechanical behavior of RPC such as compressive, flexural, and splitting tensile strengths. The objective of this research is to obtain the method of in-situ curing which reasonable good in results of the mechanical behavior of RPC. There were 4 types of curing method in this study, namely the steam curing method of $90^{\circ} \mathrm{C}$ for 8 hours in laboratory $(\mathrm{C1})$, the water curing in laboratory (C2), the in-situ steam curing with flowed steam of 3 hours per day for 7 days (C3), and the in-situ wet curing (C4). This study showed that the compressive, flexural, and splitting tensile strengths of the RPC with in-situ curing method of type C3 compared with the RPC with curing method type $\mathrm{C} 1$ have the different of $10.6 \%, 19.0 \%$, and $13.3 \%$, respectively. The in-situ curing method of type $\mathrm{C} 3$ is better than the in-situ curing method of type $\mathrm{C} 4$ in term of the strengths.
\end{abstract}

Keywords — in-situ curing method; mechanical behavior; Reactive Powder Concrete; steam curing.

\section{INTRODUCTION}

Reactive Powder Concrete (RPC) was first developed with the content of cement, fine aggregate, and water, pozzolan material in the form of silica fume, quartz powder, and superplasticizer [1]. The use of silica fume in the Reactive Powder Concrete aims to increase the homogeneity of the RPC. In this case, the RPC is more homogeneous than normal concrete. The ratio of water cement used is very low namely 0.2 . Therefore it needs superplasticizer to improve the performance of RPC. In addition to the contents of RPC, the small steel fibers and steam curing are introduced to result from the enhancement of the compressive strength and the flexural strength.

When water and cement are mixed there is a process of chemical reaction called hydration. This process does not occur instantly, but it takes a long time until the Reactive Powder Concrete reaches the final strength. The chemical reactions emit heat called hydration heat. This hydration heat can result in evaporation of water from the RPC materials. As a result, the water content in the concrete will decrease so that RPC strength growth is not as expected. Another consequence of the reduced water content is that the RPC will form clear pores and it will experience excessive shrinkage, and this will cause cracks in the RPC called crack shrinkage.

It is necessary to conduct the curing to keep the concrete moisture To ensure that the concrete hydration process can take place correctly. The curing can be done in various ways, such as using spray a special coating on the surface of the concrete, continually moisten the surface of the concrete with water, and steam.

As mention previously, the enhancement of the strength of the Reactive Powder Concrete can be done by curing with heat using the so-called steam. This can speed up the pozzolan reaction while modifying the microstructure of hydration that has been formed. Application of steam curing can be appropriately conducted in the laboratory which can be controlled with a particular temperature to achieve the best strengths of RPC.

Along with its development, the RPC is proposed to be applied for pavement of the highway. For the RPC application on the highway, therefore, is needed the curing method in the field or so-called in-situ curing. The curing method that can be done in the field is distinctly different from curing methods that can be performed in the laboratory, especially in controlling the temperature of steam curing. 
Recently, the in-situ steam curing for the application of Reactive Powder Concrete in the field can be simulated by using the method of steam curing with the temperature of $90^{\circ} \mathrm{C}$. In this case, the study indicated the compressive strength of $102 \mathrm{MPa}$ [2].

This study will use the previous in-situ steam curing method and compare it with the other in-situ method of curing and the curing methods in the laboratory to see its influence on the mechanical behavior of Reactive Powder Concrete namely compressive, flexural, and splitting tensile strengths. Through this study is expected to get the in-situ curing method that is good enough that results from the mechanical behavior of Reactive Powder Concrete.

\section{MATERIAL AND METHOD}

In the development of the Reactive Powder Concrete, quartz powder [3] is used as one of the primary constituent components to stabilize the Reactive Powder Concrete strength. Since the economic reason, the quartz powder in RPC can be replaced by glass particle from a recycled glass [4], [5]. As reported in the literature, glass particle in concrete showed quite good mechanical properties, such as compressive strength, flexural strength, and modulus of elasticity [6]. With these mechanical properties, the concrete with the glass particle is appropriate for the use of the concrete pavement of highway [7].

Besides using glass powder as one of the primary constituent components, the steel fiber is added in the RPC [8], [9], and does the steam curing, to obtain better compressive and flexural strengths as main properties of the pavement of the highway. The use of steam curing showed enhancement of the RPC strength. As reported, use of the method of steam curing in an autoclave temperature of $250^{\circ} \mathrm{C}$ to the RPC with glass powder and steel fiber can achieve a high compressive strength of $180 \mathrm{MPa}$ and a reasonable good tensile strength [10].

The maximum temperature of steam curing in the laboratory is reduced from 250 to $95^{\circ} \mathrm{C}$ to be applied in the field. Kushartomo et al. [10] indicated that in the laboratory, the steam curing with the temperature of $95^{\circ} \mathrm{C}$ for the RPC with the glass powder content of $20 \%$ resulted from the maximum of average compressive, splitting tensile, and flexural strengths are $136 \mathrm{MPa}, 17.8 \mathrm{MPa}$, and 23.2 $\mathrm{MPa}$, respectively.

Concerning the use of steam curing for the in-situ curing, Bali, et al. [2] proposed the in-situ steam curing which tarpaulins wrap the specimens and flowed steam with a temperature of $90^{\circ} \mathrm{C}$ through a duct in 3 hours per day for seven days, to investigate the compressive strength of RPC. In this case, the average compressive strength of the in-situ steam curing that can reach is $102 \mathrm{MPa}$.

In this study, some methods of curing included the method of in-situ steam curing of $90 \mathrm{oC}$ are applied to investigate mechanical behavior of RPC such as compressive, flexural, and splitting tensile strengths.

As one of the constituent components of Reactive Powder Concrete in this study, glass powder from the recycled glass material is used. Using Los Angeles abrasion machine, the glass is milled to smaller than $0.15 \mathrm{~mm}$ size with the content as much as $20 \%$ of the used cement mass. Table 1 shows the ratio of mix design for $1 \mathrm{~m} 3$ of the RPC with glass powder level of $20 \%$. The main constituent components of RPC [1] are used i.e. Portland Composite Cement (PCC), water, sand with sieve passing of $1.2 \mathrm{~mm}$, glass powder, silica fume, superplasticizer of type $\mathrm{F}$, and straight steel fiber with the diameter of $0.15 \mathrm{~mm}$ and the length of $15.0 \mathrm{~mm}$.

TABLE I

THE MIX DESIGN $\left(1 \mathrm{M}^{3}\right)$

\begin{tabular}{|c|l|l|}
\hline No. & Materials & Content $(\mathbf{k g})$ \\
\hline 1. & Water & 147.40 \\
\hline 2. & Cement (PCC) & 737.00 \\
\hline 3. & $\begin{array}{l}\text { Sand (smaller than sieve of 1.2 } \\
\text { mm) }\end{array}$ & 1105.50 \\
\hline 4. & Glass Powder (20\%) & 147.40 \\
\hline 5. & Silica Fume & 184.25 \\
\hline 6. & Superplasticizer (type F) & 22.11 \\
\hline 7. & $\begin{array}{l}\text { Steel Fiber } \\
\text { (volume of 1.5\%) }\end{array}$ \\
\hline
\end{tabular}

Four curing methods investigated in this study. It consists of two methods of curing in the laboratory and two simulated in-situ curing methods. As seen in Fig.1 and Fig. 2 , respectively, the curing method in the laboratory for the steam curing with a temperature of $90^{\circ} \mathrm{C}$ in 8 hours in 1 day (C1), and the water curing of 28 days (C2). For the simulated in-situ steam curing method (Fig. 3), the specimens are wrapped by tarpaulins and flowed steam with a temperature of $90^{\circ} \mathrm{C}$ through a duct in 3 hours per day for 7 days (C3). Fig. 4 shows the simulated in-situ wet curing method i.e. wrapping with wet sacks for 28 days (C4).

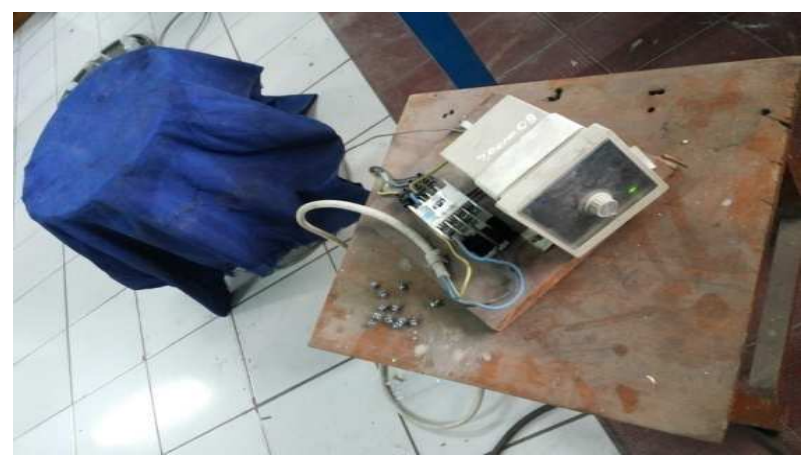

Fig. 1 The steam curing

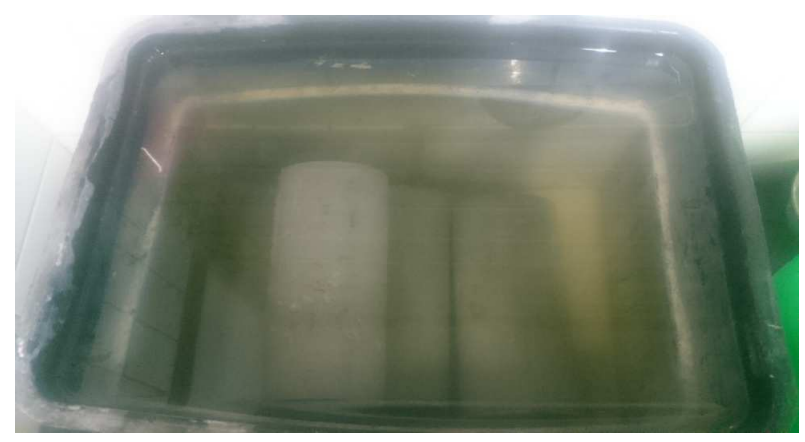

Fig. 2 The water curing 


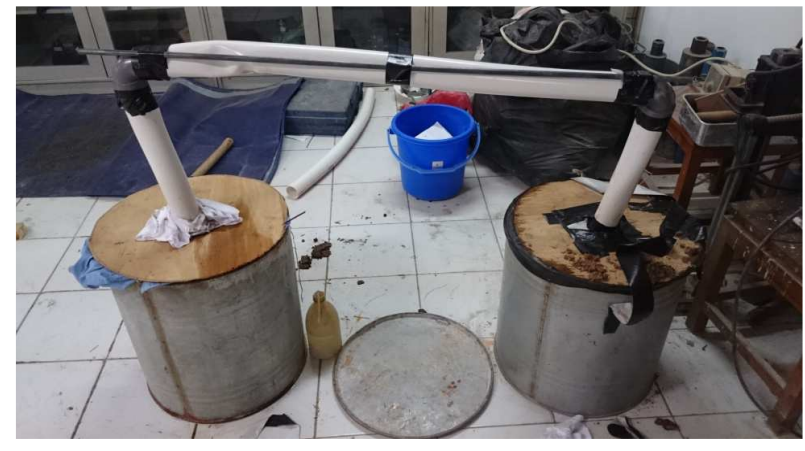

Fig. 3 The simulated in-situ steam curing

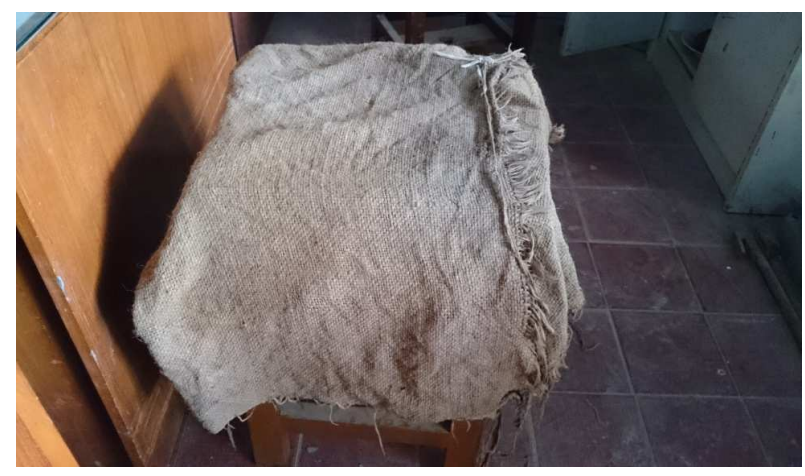

Fig. 4 The simulated in-situ wet curing

To obtain the mechanical behavior of RPC namely compressive, flexural, and splitting tensile strengths, the specimens are tested by conducting the compressive strength test (Fig. 5), the flexural strength test (Fig. 6), and the splitting tensile strength test (Fig. 7), respectively. The total of 32 specimens for compressive strength test and splitting tensile strength test are cylinder specimens with diameter (Ø) of $10 \mathrm{~cm}$ and height of $20 \mathrm{~cm}$. For the specimens of the flexural strength tests [11] are 12 beams with the size of 10 $\mathrm{cm} \times 10 \mathrm{~cm} \times 40 \mathrm{~cm}$.

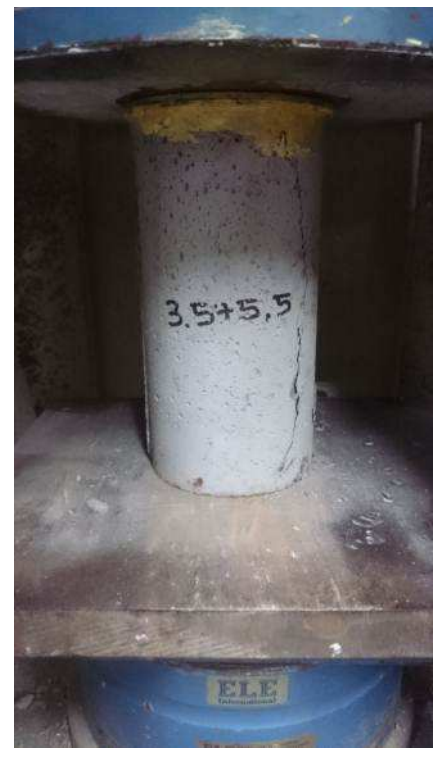

Fig. 5 The test of compressive strength

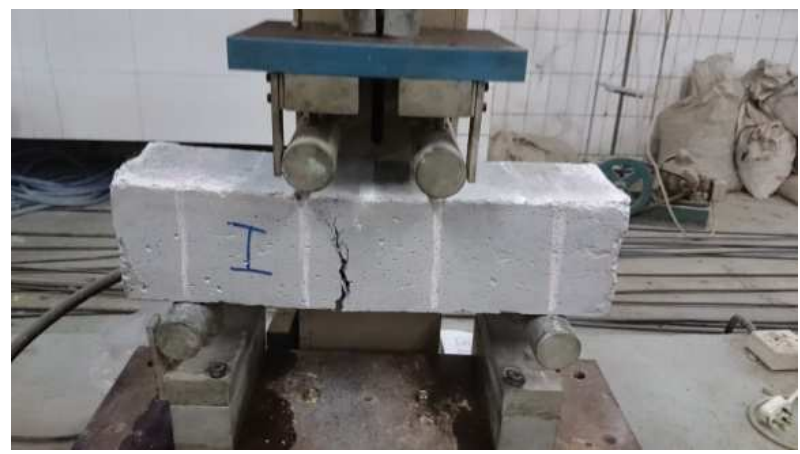

Fig. 6 The flexural strength test

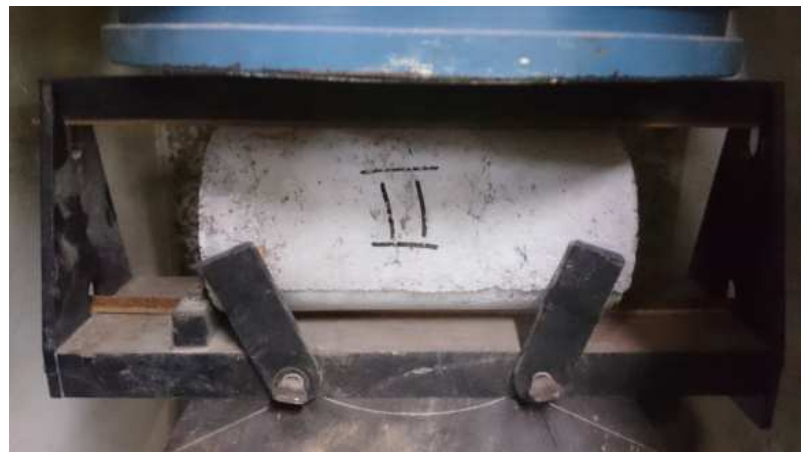

Fig. 7 The splitting tensile strength test

Concrete is considered to be strong against compressive if solid, low permeability, and more resistant to environmental influences. The compressive strength of concrete is significant because it reflects the mechanical quality and gives an indication of long-term durability. The concrete compressive strength is the ability of concrete to receive compressive forces per unit area. The equation of concrete compressive strength is written as [12]

$$
f_{c}^{\prime}=\frac{P}{A}
$$

The flexural strength of the concrete is used to find out how much stress can be retained by concrete until it reaches a cracked and broken state. The magnitude of the flexural strength is expressed in the modulus of rupture which can be determined in magnitude by using a third-point loading test. The value of modulus of rupture obtained from the third point loading test is calculated by two equations as follows. If the beam is cracked and broken exactly at a distance of one-third of the span, then the magnitude of the modulus of rupture is [13].

$$
R=\frac{P L}{b d^{2}}
$$

If the cracked and broken beam shifted as far as 5\% from a distance of one-third of the span, then the magnitude of the modulus of rupture is

$$
R=\frac{3 P a}{b d^{2}}
$$


If cracks and fractures shift more than 5\% from a distance of one-third of the spans, then the experiment should be repeated.

The splitting tensile strength is a test to determine the tensile strength of concrete indirectly. A splitting tensile strength test is used to evaluate the shear resistance of structural components made of concrete. The splitting tensile strength value can be expressed tensile stress value of concrete due to shear collapse. The splitting tensile strength testing uses a cylindrical test specimen placed horizontally on the compression test apparatus. Then the load is evenly distributed perpendicular to the entire length of the cylinder. The specimen split into two parts from end to end when the tensile strength passes. The splitting tensile strength value is calculated [14]

$$
f_{c t}=\frac{2 P}{\pi L_{c} D}
$$

\section{RESULTS AND DISCUSSION}

The total of 16 cylinder specimens for the compressive strength, 12 beam specimens for flexural strength, and 16 cylinder specimens for the splitting tensile strength were tested. It aimed to evaluate the compressive, flexural, and splitting tensile strengths of the Reactive Powder Concrete. The testing results of mechanical behavior on the Reactive Powder Concrete i.e. the compressive, flexural, and splitting tensile strengths of the Reactive Powder Concrete with the steam curing in laboratory $(\mathrm{C} 1)$, the water curing $(\mathrm{C} 2)$, the steam curing of in-situ (C3), the in-situ wet curing (C4), are showed in Table 2, Table 3, and Table 4, respectively.
The crack patterns of the Reactive Powder Concrete beams due to the flexural strength tests are also shown in Figure 8. Mostly the crack patterns are flexural cracks.

The summary of the average compressive, flexural, and splitting tensile strengths of the Reactive Powder Concrete in this study are indicated in Fig. 9, Fig. 10, and Fig. 11, respectively.

As seen in these figures, curing method of type C1 produces better compressive strength, flexural strength and splitting tensile strength with an average value of $92.61 \mathrm{MPa}$, $13.08 \mathrm{MPa}$, and $13.84 \mathrm{MPa}$, respectively. The RPC conducted with steam curing of $90^{\circ} \mathrm{C}$ in eight hours in the laboratory $(\mathrm{C} 1)$. In this study, it has a higher value than the other curing methods. It is possibly due to the presence of Tobermorite (crystals) as the result of the continued reaction of the cement hydration that is calcium hydroxide $\left(\mathrm{Ca}(\mathrm{OH})_{2}\right)$ with Silica $\left(\mathrm{SiO}_{2}\right)$ and the hardened cement paste of RPC fills the voids spaces to result in the compactness of microstructure [15].

For the steam curing methods, the RPC with the method of in-situ steam curing of type C3 compared with the RPC with steam curing method type $\mathrm{C} 1$ have the compressive, flexural, and splitting tensile strengths with the difference of $10.6 \%, 19.0 \%$, and $13.3 \%$, respectively. In this case, it is essential to consider the constant of steam temperature for the steam curing of in-situ to obtain better results.

In the case of the in-situ curing methods, the RPC with the in-situ steam curing method of type $\mathrm{C} 3$ is better than the RPC with the in-situ wet curing method of type $\mathrm{C} 4$ about $5.6 \%, 2.3 \%$, and $6.4 \%$ for the compressive, flexural, and splitting tensile strengths, respectively. This condition due to steam curing forms a faster microstructure of RPC [15].

TABLE II

THE TEST RESULTS OF COMPRESSIVE STRENGTH

\begin{tabular}{|c|c|c|c|c|c|c|c|c|}
\hline $\begin{array}{l}\text { Curing } \\
\text { Method }\end{array}$ & Specime & $\begin{array}{c}\text { Specimen } \\
\text { Age } \\
\text { (day) }\end{array}$ & $\begin{array}{c}\text { Weight } \\
\text { (g) }\end{array}$ & $\begin{array}{l}\text { Specific } \\
\text { Gravity } \\
\left(\mathrm{kg} / \mathrm{m}^{3}\right)\end{array}$ & $\begin{array}{l}\text { Average } \\
\text { Specific } \\
\text { Gravity } \\
\left(\mathbf{k g} / \mathbf{m}^{3}\right)\end{array}$ & $\begin{array}{c}P \\
(\mathbf{k N})\end{array}$ & $\begin{array}{c}f_{c}^{\prime} \\
\text { (MPa) }\end{array}$ & $\begin{array}{c}\text { Average } \\
\text { Compressive } \\
\text { Strength } \\
\text { (Mpa) }\end{array}$ \\
\hline \multirow{4}{*}{$\mathrm{C} 1$} & I & \multirow{4}{*}{3} & 3576.5 & 2275.95 & \multirow{4}{*}{2301.17} & 769.6 & 97.98 & \multirow{4}{*}{92.61} \\
\hline & II & & 3638.0 & 2315.09 & & 748.1 & 95.25 & \\
\hline & III & & 3708.0 & 2275.32 & & 783.7 & 99.79 & \\
\hline & IV & & 3674.5 & 2338.32 & & 608.0 & 77.42 & \\
\hline \multirow{4}{*}{$\mathrm{C} 2$} & $\mathrm{I}$ & \multirow{4}{*}{28} & 3598.5 & 2289.96 & \multirow{4}{*}{2306.02} & 724.3 & 92.22 & \multirow{4}{*}{91.50} \\
\hline & II & & 3589.0 & 2283.91 & & 832.2 & 106.00 & \\
\hline & III & & 3571.5 & 2357.09 & & 670.4 & 85.36 & \\
\hline & IV & & 3603.5 & 2293.14 & & 647.1 & 82.40 & \\
\hline \multirow{4}{*}{$\mathrm{C} 3$} & $\mathrm{I}$ & \multirow{4}{*}{28} & 3663.0 & 2331.00 & \multirow{4}{*}{2301.81} & 776.8 & 98.90 & \multirow{4}{*}{82.80} \\
\hline & II & & 3680.5 & 2256.23 & & 684.3 & 87.13 & \\
\hline & III & & 3704.0 & 2272.77 & & 598.9 & 76.25 & \\
\hline & IV & & 3688.5 & 2347.23 & & 541.3 & 68.92 & \\
\hline \multirow{4}{*}{$\mathrm{C} 4$} & $\mathrm{I}$ & \multirow{4}{*}{28} & 3604.0 & 2293.45 & \multirow{4}{*}{2318.99} & 667.9 & 85.04 & \multirow{4}{*}{78.15} \\
\hline & II & & 3545.5 & 2342.14 & & 563.6 & 71.76 & \\
\hline & III & & 3575.5 & 2359.64 & & 513.3 & 65.36 & \\
\hline & IV & & 3584.0 & 2280.73 & & 710.1 & 90.42 & \\
\hline
\end{tabular}


TABLE III

THE TEST RESULTS OF FLEXURAL STRENGTH

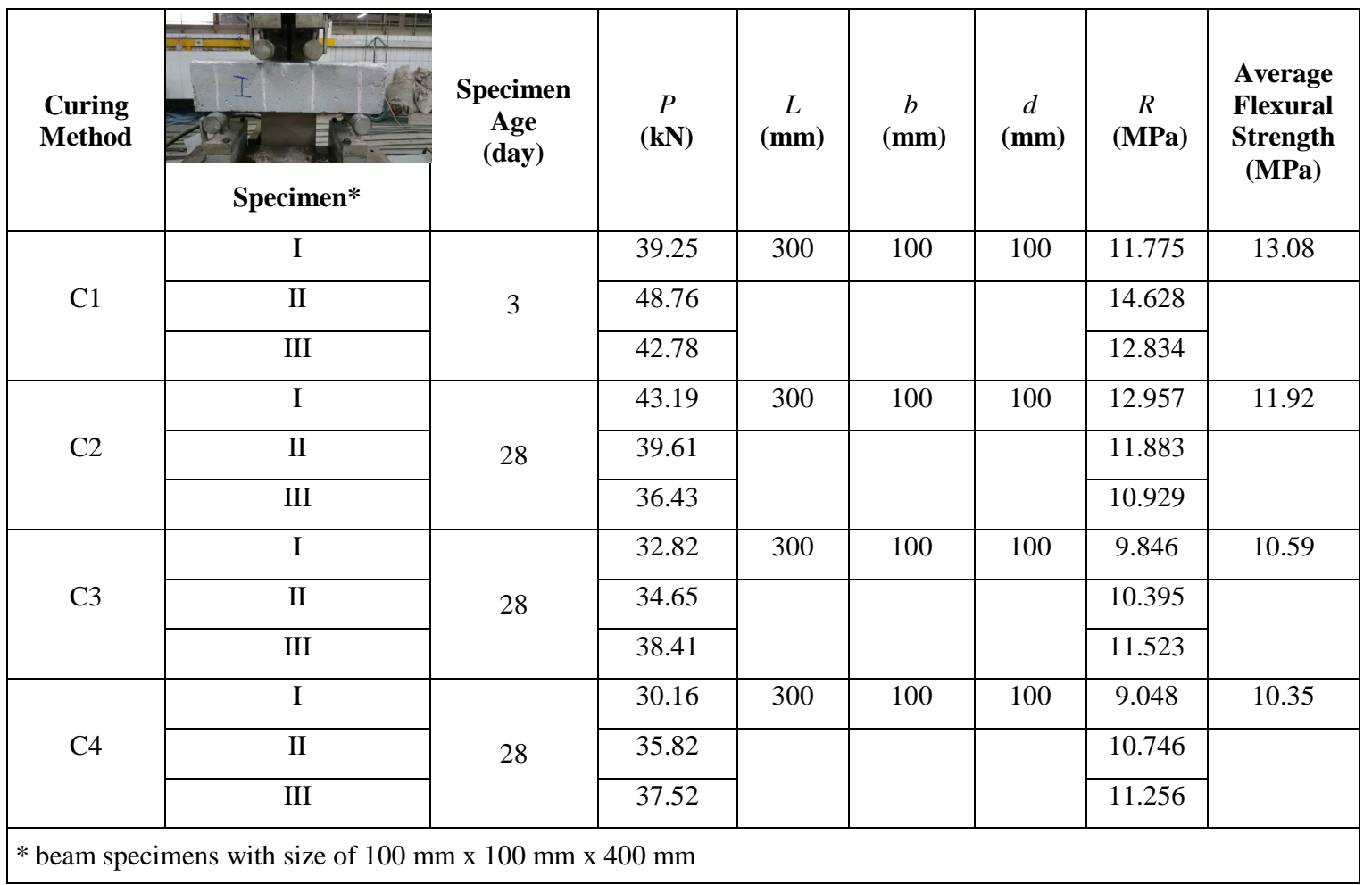

TABLE IV

THE TEST RESULTS OF SPLITTING TENSILE STRENGTH

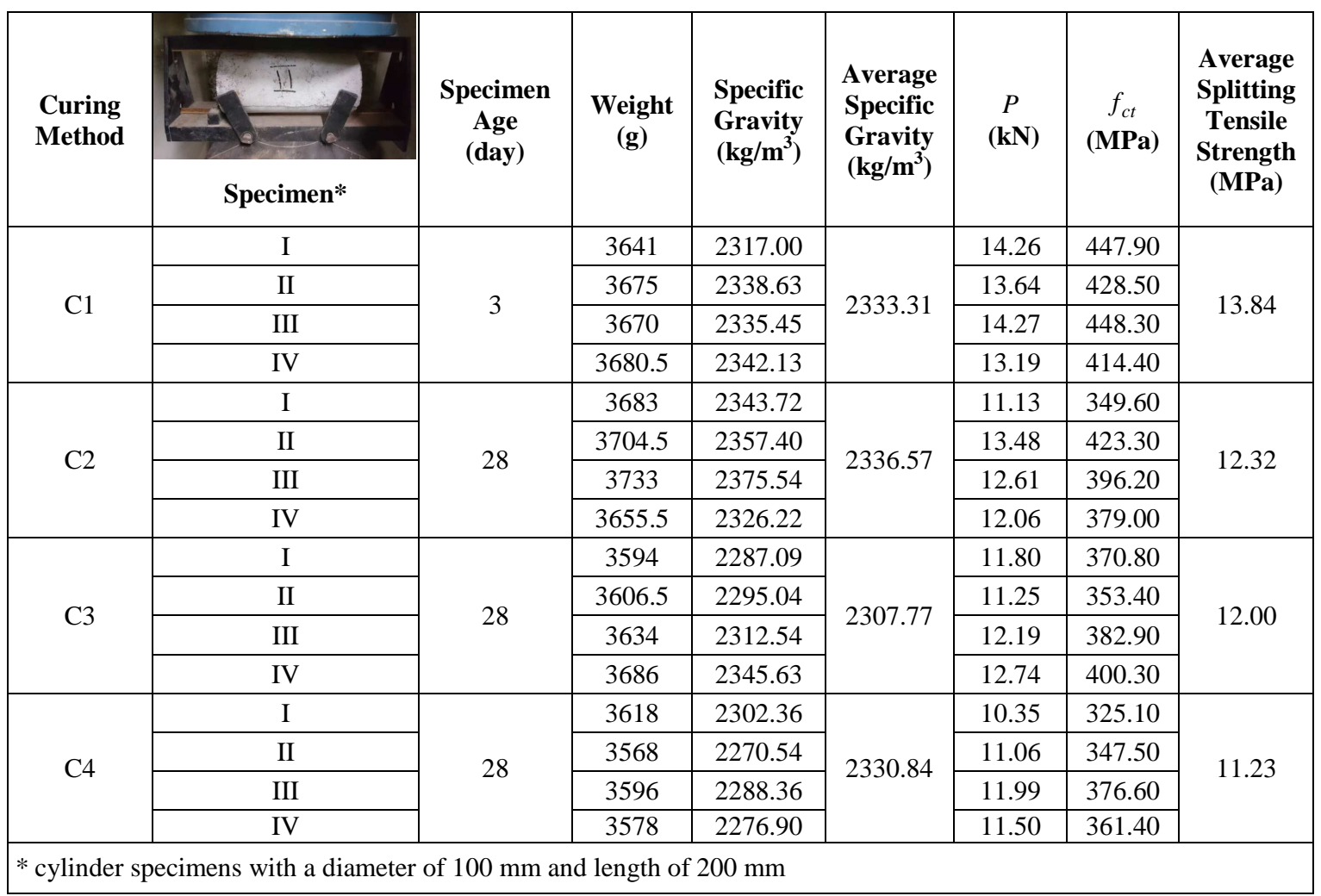




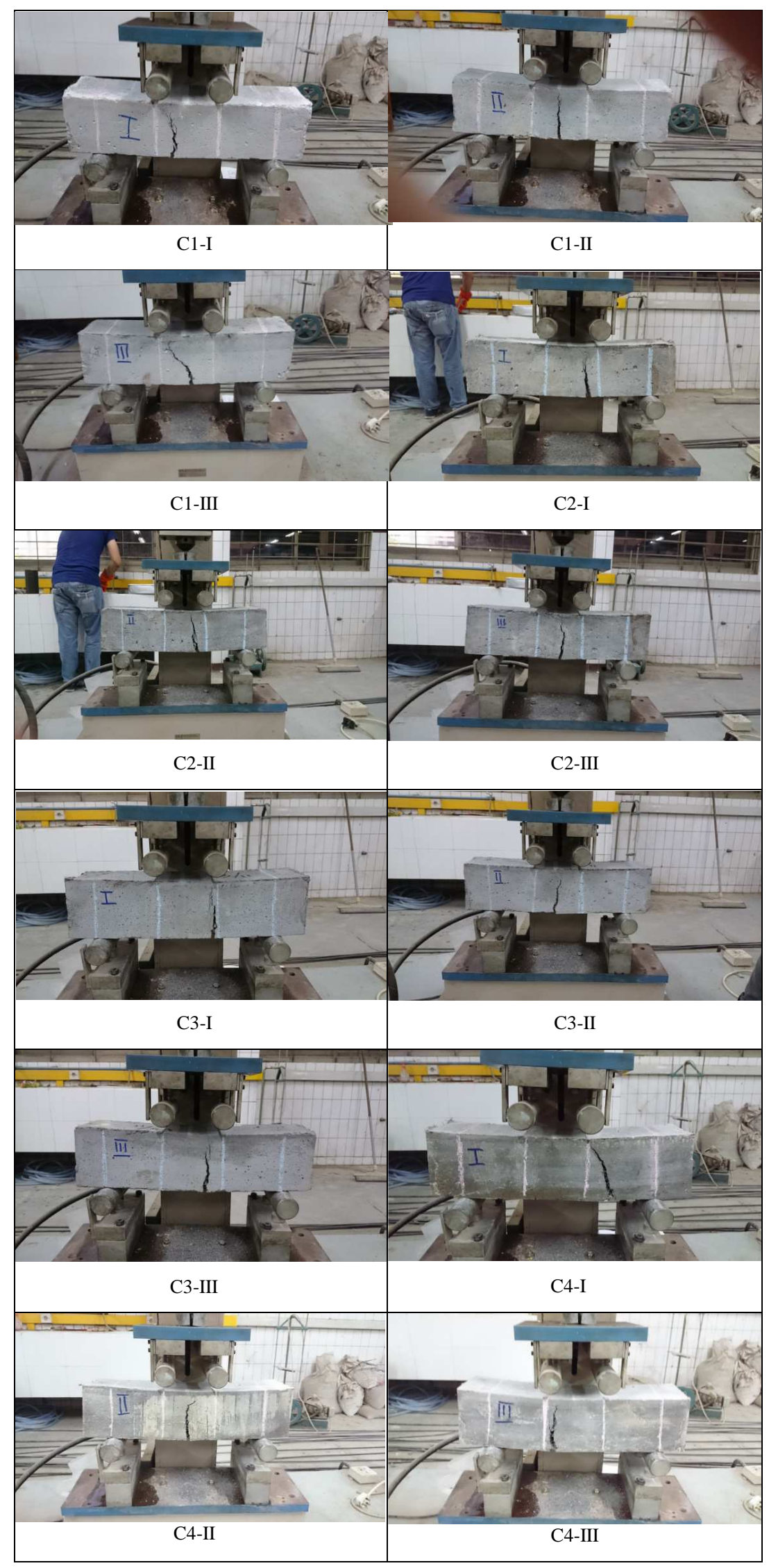

Fig. 8. The crack pattern of RPC beams due to flexural strength test 


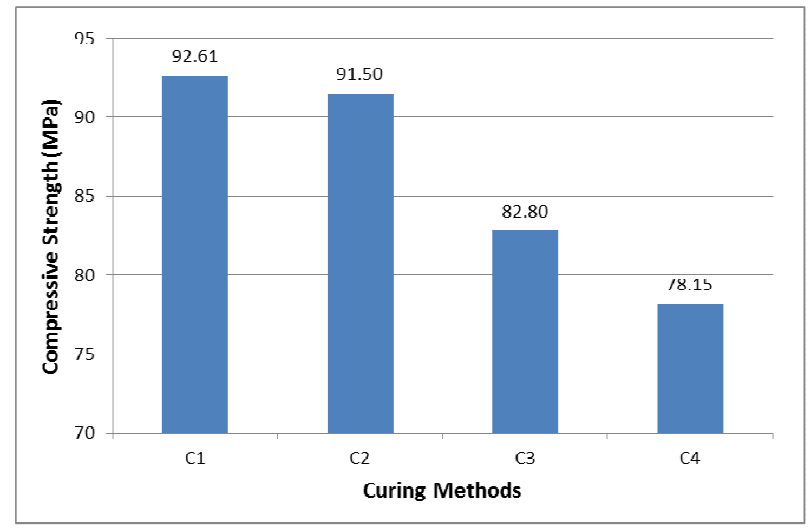

Fig. 9 The average compressive strength

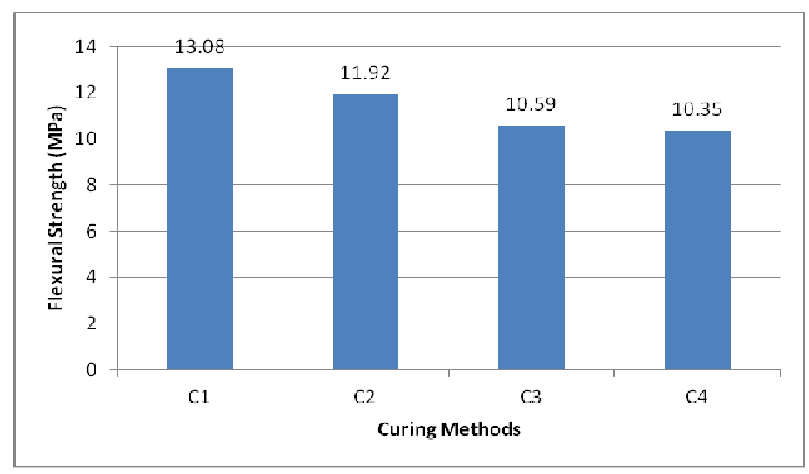

Fig. 10 The average flexural strength

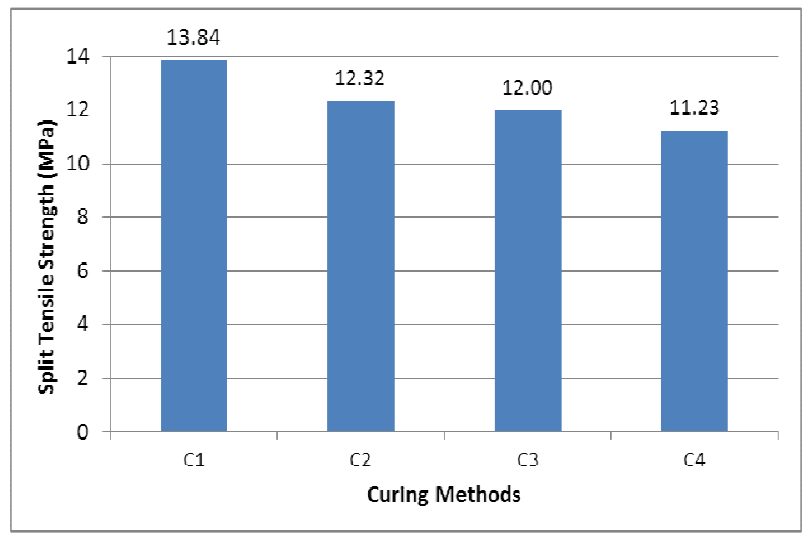

Fig. 11 The average splitting tensile strength

\section{CONCLUSIONS}

This study has conducted two types of the in-situ steam curing methods and two types of the curing methods in the laboratory to observe its influence on the mechanical behavior of Reactive Powder Concrete, i.e. the compressive, flexural, and splitting tensile strengths. This study compared four types of the curing methods. They are the steam curing method of $90^{\circ} \mathrm{C}$ in 8 hours in laboratory $(\mathrm{C} 1)$, the water curing in laboratory (C2), the in-situ steam curing which tarpaulins wrap the specimens and flowed steam with temperature of $90^{\circ} \mathrm{C}$ through a duct in 3 hours per day for 7 days $(\mathrm{C} 3)$, and the in-situ wet curing $(\mathrm{C} 4)$ to the specimens in this study.

This study indicated that the mechanical behavior of Reactive Powder Concrete such as the compressive, flexural, and splitting tensile strengths of the RPC with in-situ curing method of type C3 compared with the RPC with curing method type $\mathrm{C} 1$ have the different of $10.6 \%, 19.0 \%$, and $13.3 \%$, respectively. These results show that the in-situ curing method of type C3 or the in-situ steam curing with the flowed steam of 3 hours in 1 day for seven days is good enough and applicable to the Reactive Powder Concrete.

In a comparison of the in-situ curing methods, where the in-situ steam curing method of type C3 is compared with the in-situ wet curing method of type C4, the RPC with the insitu steam curing method of type $\mathrm{C} 3$. The result is better than the RPC with the in-situ wet curing method of type C4 with the value of $5.6 \%, 2.3 \%$, and $6.4 \%$ for the compressive, flexural, and splitting tensile strengths, respectively. This comparison shows that the in-situ curing method of type $\mathrm{C} 3$ or the in-situ steam curing which tarpaulins wrap the specimens and flowed steam with a temperature of $90^{\circ} \mathrm{C}$ through a duct in 3 hours per day for seven days. It is better than the in-situ wet curing method of type $\mathrm{C} 4$ in term of results of the RPC compressive, flexural, and splitting tensile strengths.

Based on the comparison of the strengths of the RPC compressive, flexural, and splitting tensile strengths as well as the methods of curing used in this study, then a more appropriate curing method applied in the field is the in-situ curing that covered with wet sacks for 28 days (C4). The reasons for applying the in-situ wet curing method of type $\mathrm{C} 4$ are the reasonable good achieved strengths, more comfortable to conduct and spends relatively low cost.

The future studies are needed so that the results of mechanical behavior of Reactive Powder Concrete obtained by the in-situ steam curing can produce the strengths that close to the strong results of the steam curing in the laboratory which gives quite significant strength results compared with the other methods of curing. Tarpaulins wrap the consistency factor of the temperature of flowed steam to the Reactive Powder Concrete specimens in the in-situ steam curing method of type $\mathrm{C} 3$ must be taken into account in properly.

\section{NOMENCLATURE}

$A \mathrm{n}$ area of compressive section

$\mathrm{mm}^{2}$

a distance between the cracked or broken lines to the nearest placement

$b \quad$ width of beam specimen

$D \quad$ diameter of cylinder specimen

$d \quad$ height of beam specimen

The compressive strength of concrete

$f_{c t} \quad$ Splitting tensile strength of concrete $\quad \mathrm{MPa}$

$L \quad$ length of the support span $\mathrm{mm}$

$L_{c} \quad$ length of cylinder specimen $\mathrm{mm}$

$P \quad$ maximum load that causes the breaking of the specimen

$R \quad$ modulus of rupture

$\mathrm{N}$ $\mathrm{N} / \mathrm{mm}^{2}$

\section{ACKNOWLEDGMENT}

The authors wish to thank Tarumanagara University, Jakarta for providing the technical support for conducting this research, and Matana University, Tangerang, Indonesia, for supporting the publication of this study.I 


\section{REFERENCES}

[1] P. Richard, and M. Cheyrezy, "Composition of Reactive Powder Concrete," Cement and Concrete Research, vol. 25(7), pp. 1501$1511,1995$.

[2] I. Bali, W. Kushartomo, and Jonathan, Effect of In-Situ Curing on Compressive Strength of Reactive Powder Concrete, MATEC Web of Conferences, vol. 67( 03013), pp. 1-6, 2016

[3] S. Sarika, and E. John, "A Study on Properties of Reactive Powder," International Journal of Engineering Research \& Technology (IJERT) vol. 4 (11), Nov. 2015.

[4] Concrete N. A. Soliman, and A. T. Hamou, "Using glass sand as an alternative for quartz sand in UHPC," Construction and Building Materials, vol.145, pp. 243-252, Aug. 2017

[5] V. Vaitkevičius, E. Šerelis, and H. Hilbig, "The Effect of Glass Powder on the Microstructure of Ultra High-Performance Concrete," Construction and Building Materials, vol. 68, pp. 102-109, 2014.

[6] H. Du, and K.H. Tan, Concrete with Recycled Glass as Fine Aggregates, ACI Materials Journal, vol. 111(1), pp. 47-57, Jan-Feb. 2014

[7] J.S. Sim, and K.H. Lee, "Sustainable Concrete Technology," Journal of Civil Engineering Dimension, vol. 17(3), pp.158-165, Dec. 2015.
[8] W. Zhou, H. Hu, and W. Zheng, "Bearing Capacity of Reactive Powder Concrete Reinforced by Steel Fibers," Construction and Building Materials, vol.48, pp.1179-1186, Nov. 2013.

[9] M. K. Maroliya, "A State of Art - on Development of Reactive Powder Concrete, International Journal of Innovative Research \& Development, vol. 1(8), pp.493-503, Oct. 2012.

[10] W. Kushartomo, I. Bali, and B. Sulaiman, "Mechanical Behavior of Reactive Powder Concrete With Glass Powder Substitute," Procedia Engineering, vol. 125, pp. 617-622, 2015.

[11] M. Ženíšek, T. Vlach, and L. Laiblová, "Flexural Strength of the Reactive Powder Concrete,' Solid State Phenomena, vol. 249, pp.108-111, April 2016.

[12] ASTM C39 / C39M-17b, Standard Test Method for Compressive Strength of Cylindrical Concrete Specimens, ASTM International, West Conshohocken, PA, 2017.

[13] ASTM C78 / C78M-16, Standard Test Method for Flexural Strength of Concrete (Using Simple Beam with Third-Point Loading), ASTM International, West Conshohocken, PA, 2016.

[14] ASTM C496-96, Standard Test Method for Splitting Tensile Strength of Cylindrical Concrete Specimens, ASTM International, West Conshohocken, PA, 1996.

[15] M. K. Maroliya, "Micro Structure Analysis of Reactive Powder Concrete," International Journal of Engineering Research \& Development, vol. 4(2), pp.68-77, Oct. 2012. 